\title{
Macroeconomic News and Real Interest Rates
}

\author{
Kevin L. Kliesen and Frank A. Schmid
}

\begin{abstract}
Economic news affects the perceptions of investors, forecasters, and policymakers about the strength or weakness of the economy. These expectations are updated on the basis of regularly occurring surprises in macroeconomic announcement data. The response of asset prices to positive or negative announcement surprises has been a regular feature of the literature for more than 20 years. In this vein, the authors evaluate the responses of the yield of 10-year Treasury inflationindexed securities to nearly three dozen macroeconomic announcements. They find that the real long-term rate of interest responds positively to surprises in a handful of key macroeconomic indicators, including labor productivity growth. Also, the authors find no support for the proposition that the Federal Reserve has information about its actions or the state of the real economy that is not in the pubic domain and, hence, not already priced in the real long-term interest rate.
\end{abstract}

Federal Reserve Bank of St. Louis Review, March/April 2006, 88(2), pp. 133-43.

$\square$

ederal Reserve officials often make remarks and offer their thoughts in public forums. Recent comments by Bill Poole and Janet Yellen, of the

Federal Reserve Banks of St. Louis and San Francisco, respectively, have added to the discussion of the role of economic data in monetary policy:

"I think there has been an effort to emphasize that increasingly, the policy decisions will be data-driven, driven by incoming information..."1

"Uncertainties and risks that could complicate things considerably were evident even before the havoc unleashed by Hurricane Katrina, so our approach during this phase must be particularly dependent on information from incoming data."2

1 USA Today (2005).

2 Yellen (2005).
Their comments suggest that key information is contained in the evolving flow of these data that informs policymakers' assessments of the strength of the economy and perhaps also affects the future stance of policy.

Moreover, studies with macroeconomic announcement data suggest that surprises in the data can influence such things as the market price of Treasury securities or inflation expectations. We focus our analysis on the relationship between surprise data announcements and the yield on Treasury inflation-indexed securities (TIIS, a measure of the real interest rate) from January 1997 through June 2003. Consider this example: Suppose the Federal Reserve and financial market participants view the monthly jobs number within the employment report released by the Bureau of Labor Statistics as a reliable indicator of the nearterm strength of the economy. In this case, a positive (negative) surprise would signal to the Fed and the markets that the economy was growing

Kevin L. Kliesen is an associate economist at the Federal Reserve Bank of St. Louis, and Frank A. Schmid is a senior economist at the National Council on Compensation Insurance. This article was written while Schmid was affiliated with the Federal Reserve Bank of St. Louis. The authors thank Hui Guo and Jeremy Piger for comments and suggestions. Jason Higbee provided research assistance.

(C) 2006, The Federal Reserve Bank of St. Louis. Articles may be reprinted, reproduced, published, distributed, displayed, and transmitted in their entirety if copyright notice, author name(s), and full citation are included. Abstracts, synopses, and other derivative works may be made only with prior written permission of the Federal Reserve Bank of St. Louis. 
at a quicker (slower)-than-expected pace. Under these circumstances, the demand for investment goods would be expected to increase (decrease) and the real interest rate would have to rise (fall) to clear the market.

There are many other examples of news that might affect real long-term interest rates (such as a surprise increase in labor productivity growth or in the government budget deficit). But it is not our intention here to test the theory that budget deficits cause higher interest rates or to model the real rate of interest in a macroeconomic setting. Rather, we simply test whether there is a core set of economic variables that traders in the TIIS market respond to more than others. Along these lines, other potential influences on the TIIS market are actions and commentary by Federal Reserve officials. Accordingly, we also test whether TIIS investors re-price the real long-term interest rate in response to surprises in monetary policy actions.

We look at the data from January 31,1997 , through June 30, 2003, and ask whether the real long-term rate of interest responds to a sample of 35 surprise economic announcements from that period, as well as to the surprises in the federal funds interest rate target. We measure the real long-term rate of interest of on-the-run (that is, most recently issued) 10-year TIIS. We gauge surprises in macroeconomic announcements by the difference between the expected value and the actual released value of the data series. The former is the median forecast among a sample of forecasters and market participants. Except for the growth of real GDP, the GDP price index, and nonfarm labor productivity (there are forecasts for the preliminary and revised growth rates), the latter is the first-reported value for the series.

Our analysis suggests that participants in the TIIS market respond to the announcements for seven economic data series in a statistically significant manner: business inventories, the employment cost index, the preliminary GDP estimate, initial jobless claims, new home sales, nonfarm payroll employment, and the preliminary estimate of nonfarm labor productivity. Finally, we fail to reject the hypothesis that uncertainty surrounding the real long-term interest rate is unaffected by Federal Reserve communication and surprises in monetary policy actions. Taking into consideration both those results in our analysis, we find no support for the proposition that the Federal Reserve has information about its own actions or the state of the real economy that is not in the pubic domain and, hence, priced in the real longterm interest rate.

\section{RELATED LITERATURE}

The studies most closely related to our work are Calomiris et al. (2003), Gürkaynak, Sack, and Swanson (2003), and Kohn and Sack (2003). Calomiris et al. study the response of the real interest rate, as measured by the market yield of the 10-year TIIS, to surprises in 19 macroeconomic data releases, among them the monthly federal budget deficit/surplus reported by the U.S. Treasury Department. Surprises in labor productivity or monetary policy announcements are not included in the regression. Calomiris et al. find that surprises in the federal budget surplus cause no statistically significant change in the real interest rate. Gürkaynak, Sack, and Swanson (2003) analyze the response of the forward real interest rate to surprises in macroeconomic data releases and in Federal Reserve monetary policy actions-that is, changes to the targeted federal funds rate set by the Federal Open Market Committee (FOMC). Their forward rates are derived from the yields of 10-year TIIS. ${ }^{3}$ The authors fail to reject the hypothesis that the "longterm equilibrium real rate of interest" is unaffected by surprises in these productivity and federal budget numbers. In a separate regression, Gürkaynak, Sack, and Swanson (2003) study the impact on the same dependent variable of surprises in announced changes of the targeted

\footnotetext{
3 The studied pair of 1-year forward rates applies to the 12-month time window between the maturity dates of the on-the-run 10-year TIIS and the 10-year TIIS issued 12 months earlier. Prior to July 2002, and starting in 1997, 10-year TIIS were issued only once per year, in January. This implies that the authors analyze changes to the 1-year real interest rate that is expected to prevail at the beginning of a 12-month time window that begins, on average, 8.5 years from the time of the data release. The analyzed time period runs from January 1997 through July 2002 and covers 39 macroeconomic data series.
} 
federal funds rate; again, the authors do not reject the null hypothesis of no influence. ${ }^{4}$ Faust et al. (2006) estimate a Kalman filter approach in gauging the surprise effect of macroeconomic announcements to the U.S. dollar exchange rate and to nominal (short- and long-term) interest rates. These authors find that the surprises in such announcements for a wide variety of macroeconomic variables have a statistically significant effect on the dollar and interest rates.

Kohn and Sack (2003) study the effect of Federal Reserve communication on financial variables using daily observations for the period January 3, 1989, through April 7, 2003. In their analysis, Fed communication comprises statements released by the FOMC and, since June 1996, Congressional testimonies and speeches delivered by the Chairman of the Federal Reserve. Kohn and Sack make no attempt to gauge the influence on the level of Treasury yields; rather, the authors measure the effect of Fed communication on Treasury yield volatility. Kohn and Sack investigate the effect that Federal Reserve communication has on various financial variables, such as the yields (to maturity) of the nominal 2-year and 10-year Treasury notes. Kohn and Sack find that statements of the FOMC and testimonies of the Chairman of the Federal Reserve have a statistically significant impact on the variance of 2-year and 10-year Treasury note yields; no such influence was found for the Chairman's speeches. We build on Kohn and Sack when studying the effect of Federal Reserve communication on the (conditional) variance of the yield of the 10-year TIIS or, put differently, on the uncertainty that surrounds the real long-term rate of interest.

\section{THE DATA}

Our analysis covers the period from January 31, 1997, through June 30, 2003. The starting date of this sample period is determined by the availability of the 10-year TIIS yield; the ending date

\footnotetext{
4 These findings of surprises in macroeconomic data releases and monetary policy actions on real interest rates are included only in the Gürkaynak, Sack, and Swanson working paper (2003) but not in the published version (Gürkaynak, Sack, and Swanson, 2005).
}

is determined by the series of macroeconomic data releases provided by Money Market Services (MMS). The dataset comprises median polled forecast values for 38 macroeconomic data series, along with the sample standard deviations of these forecast values. The MMS survey is conducted every Friday morning among senior economists and bond traders with major commercial banks, brokerage houses, and some consulting firms, mostly in the greater New York, Chicago, and San Francisco areas. Among these 38 variables in the survey, there are three items-CPI, PPI, and retail sales-for which there also exists a "core" measure. Although the comprehensive versions of the CPI and the PPI include food and energy items, the respective core measures do not. For retail sales, the narrowly defined concept excludes motor vehicles and parts. In the regression analysis, we use the core concepts only; this leaves us with 35 macroeconomic variables. ${ }^{5}$

We relate daily changes in the real long-term rate of interest to the surprise component in macroeconomic data releases. Like Gürkaynak, Sack, and Swanson (2003), we define the surprise component as the difference between the actual and the median forecast values; but unlike these authors (and unlike Calomiris et al.), we normalize these surprises by the sample standard deviation of the individual forecasts, which we take to be a measure of forecaster uncertainty surrounding these expectations. In the literature, normalizing announcement surprises, though common, is not universal. ${ }^{6}$ We also control for the surprise component in changes (or the absence thereof) of the targeted federal funds rate, which we measure as suggested by Kuttner (2001) and discussed by Watson (2002). For each scheduled and unsched-

5 We find no statistically significant difference, for any of our statistical analyses, between the core and the comprehensive measures.

6 Fleming and Remolona $(1997,1999)$ calculate the surprise component by normalizing the difference between the actual and the forecast values by the mean absolute difference observed for the respective variable during the sample period. Balduzzi, Elton, and Green (2001) normalize the difference between the actual and the forecast values by the standard deviation of this difference during the sample period. Gürkaynak, Sack, and Swanson (2005) normalize the announcement surprise by its standard error. Faust et al. (2006) simply use a non-normalized forecast error (surprise) in their analysis of intraday exchange rate and nominal interest rate data. 
uled FOMC meeting, we scaled up by $30 /(k+1)$ the change of the price of the federal funds futures contract for the current month on the day of the FOMC meeting, $t$, where $t+k$ denotes the last calendar day of the month. ${ }^{7}$ (Note that this variable is not on the same scale as the surprise component in the macroeconomic data releases.) In a sensitivity analysis, we use an alternative measure of the surprise component in monetary policy actions; this alternative measure, devised by Poole and Rasche (2000), rests on price changes of federal funds futures contracts also. ${ }^{8}$ Finally, we control for Federal Reserve communication and actions. Our concept of Federal Reserve communication comprises (i) the Fed Chairman's semiannual testimony to Congress (formerly known as Humphrey-Hawkins testimony) and (ii) speeches and other testimonies of the Fed Chairman.

In announcement studies, the timing of the data releases can sometimes be an issue. This is particularly true if intraday observations are used. In this paper, there are two potential timing issues, neither of which is likely to significantly influence the results because we do not use intraday prices. First, most data releases occur in the morning at 8:30 and 10:00 eastern standard time. However, there are some releases that occur in the afternoon, such as consumer credit and the budget surplus/ deficit, and some that have an irregular release time (auto and truck sales). This is also the case with Fed speeches and testimonies, which can occur when markets are open or closed. A second potential issue are data releases and speeches that occur on holidays or when the markets are closed. Data releases on days when the markets were closed were moved to the next trading day (the day on which this information was priced in the marketplace). We also moved Federal Reserve communication to the next trading day if this communication occurred after hours (that is, after the real interest rate had been recorded)

\footnotetext{
7 Following Gürkaynak, Sack, and Swanson (2003), we use the (unscaled) change in the price of the federal funds futures contract due to expire in the following month if the FOMC meeting took place within the last seven calendar days of the month.

8 See Gürkaynak, Sack, and Swanson (2002) for a discussion of how measures of market expectations are measured in relation to monetary policy actions.
}

or on days on which there was no trading. Thus, in some cases, U.S. markets will have a shorter time period in which to react to the announcement surprise, while in other cases they will have a longer time period.

Table 1 shows the frequency of the macroeconomic announcements during the period of analysis (January 1997 through June 2003). The number in parentheses-the number of data releases during the analyzed time period-differs because of missing values in the recorded real interest rate. For example, there are 77 observations (surprises) for most monthly variables, such as business inventories. Of the 77 observations for business inventories, 68 were used. Note that Table 1 also includes two monetary policy variables and one Fed communication variable. We also report matches for scheduled and unscheduled FOMC meetings-the federal funds target variable, the surprise component of which was calculated as outlined above-and the two Federal Reserve communication variables defined above. The only weekly series in the dataset, initial jobless claims, has the highest frequency. The nextto-highest frequency is observed for testimonies other than semiannual testimony to Congress, followed by monthly data releases, FOMC actions (federal funds target), quarterly data releases, and the Chairman's semiannual testimonies to Congress. An exception is nonfarm productivity, which entered the MMS dataset during the analyzed time period. The first surveyed number refers to the first quarter of 1999.

Table 2, center column, offers a frequency distribution for the coincidence of surprises in macroeconomic data releases (MMS survey) and monetary policy actions. For instance, in the sample period of 1,527 trading days, there are 445 trading days on which there were no surprises in data releases or monetary actions, possibly because no data were released or no action taken. There are 600 trading days (39 percent) with more than one surprise and 268 trading days (18 percent) with more than two surprises. Table 2 (right column) offers a frequency distribution with Federal Reserve communication included. 


\section{Table 1}

\section{Number of Total Macroeconomic Announcements and Monetary Policy Variables that Correspond with Daily Inflation Compensation Observations}

Data series

Auto sales

Business inventories

Capacity utilization

Civilian unemployment rate

Construction spending

Consumer confidence

Consumer credit

Consumer price index (CPI-U)

CPI excluding food and energy (CPI-U, "core")

Durable goods orders

Employment cost index (Q)

Existing home sales

Factory orders

Federal funds target: unscheduled FOMC meeting

Federal funds target: scheduled FOMC meeting

GDP price index (advance) $(Q)$

GDP price index (preliminary) $(\mathrm{Q})$

GDP price index (final) (Q)

Goods and services trade balance (surplus)

Chairman's speeches and testimonies

Hourly earnings

Housing starts

Industrial production

Initial jobless claims (W)

Leading indicators

Purchasing managers index (PMI)

New home sales

Nonfarm payrolls

Nonfarm productivity (preliminary)

Nonfarm productivity (revised)

Personal consumption expenditures

Personal income

Producer price index (PPI)

PPI excluding food and energy ("core")

Real GDP (advance) (Q)

Real GDP (final) (Q)

Real GDP (preliminary) (Q)

Retail sales

Retail sales excluding autos ("core")

Treasury budget (surplus)

Truck sales
Total (actual used)

77 (68)

$77(67)$

$77(67)$

$77(67)$

$77(72)$

$77(69)$

$77(72)$

$77(74)$

$77(74)$

77 (69)

$25(25)$

$61(56)$

$77(72)$

4 (4)

$52(50)$

$26(26)$

$26(22)$

$26(23)$

77 (74)

145 (137)

$74(63)$

77 (73)

77 (67)

334 (306)

78 (73)

77 (65)

78 (74)

77 (66)

17 (16)

17 (17)

78 (62)

$78(62)$

77 (67)

77 (67)

26 (26)

26 (22)

26 (23)

$77(72)$

$77(72)$

$77(71)$

77 (68)

NOTE: Variables not included in the dataset of macroeconomic data releases are italicized. Monthly series if not indicated otherwise (Q: quarterly; W: weekly). Numbers in parentheses indicate actual number of observations used in the analysis; this number differs from total because of missing observations for the measures of inflation compensation due to holidays or unreported values. 
Table 2

Frequency Distribution of Concurrence in Surprises

\begin{tabular}{ccc}
$\begin{array}{c}\text { Number of surprises } \\
\text { per trading day }\end{array}$ & $\begin{array}{c}\text { MMS survey and } \\
\text { federal funds target }\end{array}$ & $\begin{array}{c}\text { MMS survey, federal funds target, } \\
\text { and Federal Reserve communication }\end{array}$ \\
\hline 0 & 445 & 410 \\
1 & 482 & 478 \\
2 & 332 & 343 \\
3 & 147 & 159 \\
4 & 82 & 94 \\
5 & 21 & 24 \\
6 & 12 & 12 \\
7 & 3 & 3 \\
8 & 1 & 2 \\
9 & 2 & 2 \\
Total & 1,527 & 1,527 \\
\hline
\end{tabular}

\section{EMPIRICAL APPROACH AND FINDINGS}

The empirical approach rests on the following regression equation:

$$
r_{t}-r_{t-1}=\alpha+\beta \cdot D+\sum_{k=1}^{35} k \cdot x_{t}^{k}+\gamma \cdot f f_{t}+\varepsilon_{t},
$$

where $r_{t}-r_{t-1}$ is the change in the real interest rate from trading day $t-1$ to trading day $t$; $D$ is an indicator variable that is equal to 1 if all explanatory variables are equal to 0 (and is equal to 0 otherwise); $x_{t}^{k}$ is the surprise component in the macroeconomic data release; $f f_{t}$ is the surprise component in the Federal Reserve action (the federal funds target variable); and $\varepsilon_{t}$ is an error term. ${ }^{9}$

The change in the real long-term interest rate is measured by the daily change in the on-the-run 10-year TIIS yield. Although the Treasury has in the past issued 5- and 20-year and a small number of 30-year TIIS, we focus solely on the 10-year yield because that is the maturity that has been continuously issued since 1997. Figure 1 shows

\footnotetext{
9 The intercept indicator variable, $D$, eliminates the influence of certain observations on the observed mean of the dependent variable-specifically, those observations for which none of the explanatory variables contains information pertinent to the measured inflation compensation.
}

a kernel estimate of the distribution of this dependent variable (thick line), along with a frequency distribution (candlesticks) and a normal distribution (blue line) based on the sample moments. The change in the real interest rate exhibits statistically significant excess kurtosis (5.164) and mild but statistically significant skewness (0.401). ${ }^{10}$

Table 3 shows the results of regression equation (1). The table shows traditional $t$ values andbecause of the excess kurtosis of the dependent variable-significance levels obtained from distribution free bootstrap $t$ intervals (see Efron and Tibshirani, 1993). The empirical results reported in the table suggest that there are seven economic announcements that matter: business inventories, the employment cost index, the annualized rate of growth of the GDP price index (preliminary estimate), initial jobless claims, new home sales, nonfarm payroll employment, and the preliminary estimate of nonfarm labor productivity. With the exception of new home sales, each of the coefficients has the predicted sign. That is, stronger-

\footnotetext{
10 Excess kurtosis means that, compared with the normal distribution, there is excess probability mass in the center of the distribution. We use a Gaussian kernel along with an (under the null of normal distribution) optimal bandwidth of $(4 / 3)^{0.2} \cdot \hat{\sigma} \cdot T^{-0.2}$, where $T$ is the number of sample observations and $\hat{\sigma}$ is the sample standard deviation (Silverman, 1986).
} 


\section{Table 3}

\section{On-the-Run 10-year TIIS Yield and Data Surprises}

Explanatory variable
Auto sales
Business inventories
Capacity utilization
Civilian unemployment rate
Construction spending
Consumer confidence
Consumer credit
Consumer price index (CPI-U, "core")
Durable goods orders
Employment cost index
Existing home sales
Factory orders
Federal funds target
GDP price index (advance)
GDP price index (preliminary)
GDP price index (final)
Goods and services trade balance (surplus)
Hourly earnings
Housing starts
Industrial production
Initial jobless claims
Leading indicators
Purchasing managers index (PMI)
New home sales
Nonfarm payrolls
Nonfarm productivity (preliminary)
Nonfarm productivity (revised)
Personal consumption expenditures
Personal income
Producer price index (PPI, "core")
Real GDP (advance)
Real GDP (preliminary)
Real GDP (final)
Retail sales, excluding motor vehicles and parts ("core")
Treasury budget (surplus)
Truck sales
Intercept indicator variable (D)
Intercept

F-statistic (1)

F-statistic (2)

$R^{2}$

$R^{2}$ adj.

Ljung-Box statistic

Rao's score test

Number of nonzero observations

Number of observations

\section{Coefficient}

$-2.715 \cdot 10^{-3}$

$-4.176 \cdot 10^{-3}$

$1.476 \cdot 10^{-4}$

$-2.471 \cdot 10^{-3}$

$-7.883 \cdot 10^{-4}$

$1.184 \cdot 10^{-3}$

$1.425 \cdot 10^{-3}$

$-3.002 \cdot 10^{-3}$

$4.171 \cdot 10^{-4}$

$4.972 \cdot 10^{-3}$

$1.921 \cdot 10^{-4}$

$-1.467 \cdot 10^{-4}$

$7.257 \cdot 10^{-2}$

$6.833 \cdot 10^{-4}$

$1.748 \cdot 10^{-3}$

$-1.595 \cdot 10^{-3}$

$-1.039 \cdot 10^{-3}$

$-8.496 \cdot 10^{-4}$

$3.213 \cdot 10^{-4}$

$4.051 \cdot 10^{-3}$

$-2.009 \cdot 10^{-3}$

$9.660 \cdot 10^{-3}$

$2.855 \cdot 10^{-3}$

$-2.990 \cdot 10^{-3}$

$3.840 \cdot 10^{-3}$

$5.764 \cdot 10^{-3}$

$-3.469 \cdot 10^{-3}$

$-3.529 \cdot 10^{-3}$

$-2.310 \cdot 10^{-3}$

$-9.685 \cdot 10^{-5}$

$1.695 \cdot 10^{-3}$

$-3.731 \cdot 10^{-3}$

$-5.376 \cdot 10^{-3}$

$-2.279 \cdot 10^{-4}$

$-2.545 \cdot 10^{-3}$

$2.776 \cdot 10^{-3}$

$1.724 \cdot 10^{-3}$

$-1.342 \cdot 10^{-3}$
t-Statistic

$-0.948$

$-2.114^{* *}$

0.056

$-1.587$

$-0.486$

0.730

1.210

$-1.245$

0.379

$1.978^{* *}$

0.237

$-0.051$

1.075

0.388

2.456**

$-0.880$

$-0.530$

$-0.520$

0.165

1.028

$-3.103^{* * *}$

1.395

1.226

$-1.739 *$

$3.057^{* * *}$

$2.263^{* *}$

$-0.818$

$-0.848$

$-0.773$

$-0.050$

0.690

$-1.282$

$-1.498$

$-0.094$

$-0.958$

0.847

1.062

$-1.212$

NOTE: ${ }^{* * *} / * * / *$ Indicates significance at the $1 / 5 / 10$ percent levels, respectively ( $t$-tests are two-tailed). $F$-statistics and $t$-statistics are Newey and West (1987) corrected. Federal funds target is not included in the MMS survey. $F$ statistic (1): all MMS survey variables and federal funds target; $F$-statistic (2): all MMS survey variables. The number of nonzero observations indicates the number of trading days where there was a surprise in a macroeconomic data release or a monetary policy action priced in the market. 
Table 4

\section{Instrumental-Variables Approach}

\begin{tabular}{lccc} 
Explanatory variable & Coefficient & t-Statistic & Bootstrap \\
\hline Federal funds target (GSS) & $1.281 \cdot 10^{-1}$ & 1.517 & Not significant \\
Federal funds target (PR) & $1.185 \cdot 10^{-1}$ & 1.538 & Not significant
\end{tabular}

NOTE: Neither regression coefficient is statistically significant ( $t$-tests are two-tailed; $t$-statistics are Newey and West (1987) corrected). GSS and PR indicate the federal funds market measure for monetary policy surprises as suggested by Gürkaynak, Sack, and Swanson (2002) and Poole and Rasche (2000), respectively.

\section{Figure 1}

\section{Distribution of Daily Changes in the Real Long-Term Interest Rate}

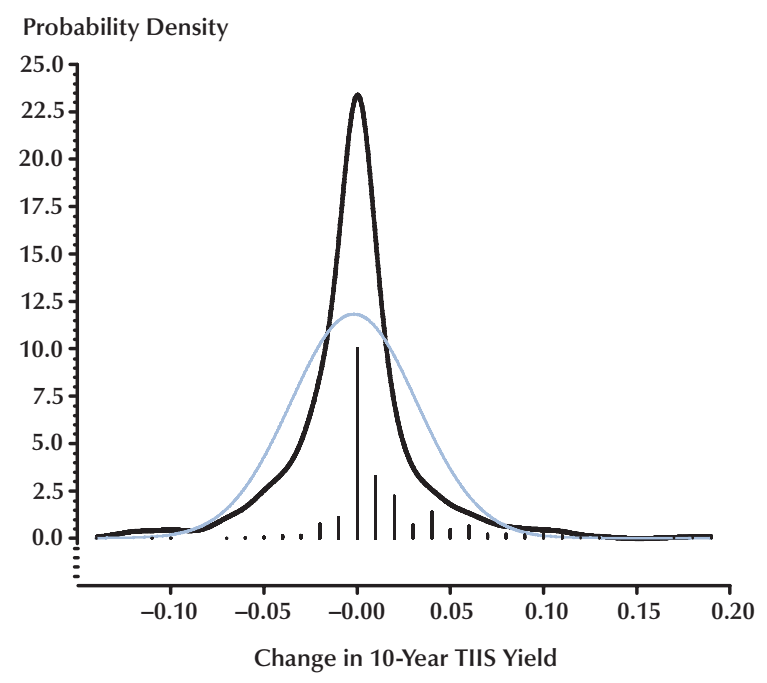

than-expected economic growth raises the real rate of interest. Recall that the announcement surprises have been normalized by the sample standard deviation of the individual forecasts (measured over the entire sample). If strongerthan-expected economic growth arises from a productivity shock, then that growth raises the desired capital stock; the real rate of interest must rise to restore the goods-market equilibrium. Indeed, our results show that we can reject the null hypothesis that surprises in productivity growth have no impact on the real long-term rate of interest.
Two other potentially interesting results from Table 3 are worth mentioning. First, our results suggest that surprise changes in the federal budget deficit (surplus) have no discernable impact on market participants who buy and sell 10-year TIIS. Second, a surprise increase in inflation (growth of the GDP price index) is expected to raise the real long-term interest rate. The latter result is perhaps puzzling given that the long-term real interest rate is thought to be determined by real factors (capital formation, productivity growth, population, etc.). The $R^{2}$ in Table 3 is about 5 percent, which implies that surprises in macroeconomic announcements explain only 5 percent of the variation of the dependent variable around its mean, the remainder being noise. Overall, the results from Table 3 suggest that the real long-term interest rate can change in response to surprise increases in some macroeconomic data releases, but that other factors appear to be more economically significant.

The results in Table 3 also allow us to speculate about the hypothesized linkage between the effects of surprise changes in the federal funds target rate. We find that surprises in changes of the targeted federal funds rate have no discernable impact on the real rate of interest. This finding squares with Weiss (2006), who finds no measurable effect of the federal funds rate (as derived from futures contracts) on the 10-year TIIS yield. Poole, Rasche, and Thornton (2002) argue that monetary policy surprises as gauged by changes in federal funds futures prices are measured with error. This is because federal funds futures prices not only change in response to monetary policy actions, but also respond to other information 


\section{Table 5}

\section{Uncertainty about Real Interest Rates}

\begin{tabular}{|c|c|c|c|}
\hline Explanatory variable & Coefficient & t-Statistic & Bootstrap \\
\hline \multicolumn{4}{|c|}{ Panel A: GSS measure of federal funds target surprises } \\
\hline Federal Reserve communication & $-2.217 \cdot 10^{-4}$ & -0.493 & \\
\hline Federal funds target & $4.209 \cdot 10^{-3}$ & 0.689 & \\
\hline Intercept indicator variable (D) & $-4.828 \cdot 10^{-4}$ & -1.056 & \\
\hline Intercept & $1.243 \cdot 10^{-3}$ & $2.774 * * *$ & $* *$ \\
\hline Number of nonzero observations & 180 & & \\
\hline Number of observations & 1,527 & & \\
\hline \multicolumn{4}{|c|}{ Panel B: PR measure of federal funds target surprises } \\
\hline Federal Reserve communication & $-1.139 \cdot 10^{-4}$ & -0.265 & \\
\hline Federal funds target & $5.118 \cdot 10^{-3}$ & 0.653 & \\
\hline Intercept indicator variable (D) & $-3.759 \cdot 10^{-4}$ & -0.859 & \\
\hline Intercept & $1.137 \cdot 10^{-3}$ & $2.657^{* * *}$ & * \\
\hline Number of nonzero observations & 182 & & \\
\hline Number of observations & 1,527 & & \\
\hline \multicolumn{4}{|c|}{$\begin{array}{l}\text { NOTE: } * * * / * * * \text { Indicates significance at the } 1 / 5 / 10 \text { percent levels, respectively ( } t \text {-tests are two-tailed). GSS and PR indicate the federal } \\
\text { funds market measure for monetary policy surprises as suggested by Gürkaynak, Sack, and Swanson (2002) and Poole and Rasche (2000), } \\
\text { respectively. The variable Federal Reserve Communication equals } 1 \text { on trading days on which the Chairman of the Federal Reserve's } \\
\text { semiannual testimony to Congress (formerly known as Humphrey-Hawkins Testimony) or speeches and other testimonies of the Fed } \\
\text { Chairman were priced in the market. The number of nonzero observations indicates the number of trading days where there was a } \\
\text { surprise in a macroeconomic data release or a monetary policy action priced in the market. }\end{array}$} \\
\hline
\end{tabular}

pertinent to the future path of the federal funds rate. Because of the measurement error introduced by such ambient price changes of federal funds futures contracts, the regression coefficient of the federal funds target variable is biased toward 0 . We account for this error-in-variable problem with an instrumental variables approach. We use as an instrument for the federal funds target an indicator equal to 1 if the federal funds target exceeds its median positive value, equal to -1 if it falls short of its median negative value, and equal to 0 otherwise. ${ }^{11}$

Table 4 shows the regression results of the instrumental variables approach applied to equation (1). We use two alternative definitions of the surprise component of monetary policy actions (the federal funds target variable). First, we provide results for the concept that we used above- the

\footnotetext{
${ }^{11}$ For details on this error-in-variable approach, see Greene (2003).
}

measure suggested by Gürkaynak, Sack, and Swanson (2003), which is denoted federal funds target (GSS) in the table. Second, we present results for the surprise measure devised by Poole and Rasche (2000); this measure is denoted federal funds target (PR) in the table. Unlike the GSS measure, which rests on the scaled price change of the current month's federal funds futures contract (unless the monetary policy surprise happens within the last seven days of the month), the PR measure always uses the price change of the next month's federal funds futures contract. For the GSS measure, the regression coefficient for the federal funds target variable is indeed larger (in absolute value) than it is without the error-in-variable correction (shown in Table 3) but remains statistically insignificant. But, for the PR measure, the regression coefficient for the federal funds target variable is smaller (in absolute value) than it is without the error-in-variable correction (not shown); it remains statistically insignificant as well. 
We have been unable to establish evidence that monetary policy actions of the Federal Reserve affect the real long-term rate of interest. But the Federal Reserve has another channel of influence-communication. As discussed above, the surprise component in Federal Reserve communication is next to impossible to ascertain. Yet, following Kohn and Sack (2003), we can analyze the effect of Federal Reserve communication on the (conditional) variance of the dependent variable; this variance may be viewed as a measure of uncertainty that surrounds the future path of real short-term interest rates. Note that, if Federal Reserve communication and surprises in monetary policy actions affect the uncertainty surrounding the real rate of interest, then the error term of the regression equation (1) is heteroskedastic; Rao's score test on heteroskedasticity indeed rejects the null hypothesis that there is no such heteroskedasticity. ${ }^{12}$

We study the impact of Federal Reserve communication and surprises in monetary policy action on real interest rate uncertainty by analyzing the squared residuals from regression equation (1) - as shown in Table 3-in an estimation approach suggested by Amemiya $(1977,1978)$. We regress these squared residuals on (i) the (absolute value of the) federal funds target variable, an indicator variable that is equal to 1 on days when Federal Reserve communication was priced in the market and 0 otherwise and (ii) the previously introduced intercept indicator variable (D). The regression results, presented in Table 5, indicate that neither Federal Reserve communication nor monetary policy surprises influence the conditional variance of the real rate of interest. Hence, we do not reject the hypothesis that neither surprises in Federal Reserve monetary policy action nor Federal Reserve communication affect the uncertainty surrounding the real long-term interest rate.

\section{CONCLUSION}

The results in this paper suggest that real interest rates-as measured by market yields on

${ }^{12}$ For Rao's score test, see Amemiya (1985).
Treasury inflation-indexed securities-respond to surprise announcements of macroeconomic data. Our findings are consistent with economic theory, which suggests that stronger-than-expected growth, perhaps caused by surprises in productivity growth, affects the real long-term interest rate. In the case of nonfarm productivity growth, the greater the surprise in the released nonfarm productivity growth number, the greater the accompanying increase in the real long-term rate of interest. We found no evidence that surprise increases in the monthly federal budget deficit increase the real rate of interest. Further, we find no evidence supporting the proposition that Federal Reserve communication or surprises in monetary policy actions - as gauged by changes in the targeted federal funds rate-influence the expected value or variance of the real long-term interest rate.

\section{REFERENCES}

Amemiya, Takeshi. "A Note on a Heteroscedastic Model." Journal of Econometrics, November 1977, 6(3), pp. 365-70.

Amemiya, Takeshi. "Corrigenda." Journal of Econometrics, October 1978, 8(2), p. 275.

Amemiya, Takeshi. Advanced Econometrics. Cambridge, MA: Harvard University Press, 1985.

Balduzzi, Pierluigi; Elton, Edwin J. and Green, T. Clifton. "Economic News and Bond Prices: Evidence from the U.S. Treasury Department." Journal of Financial and Quantitative Analysis, December 2001, 36(4), pp. 523-43.

Calomiris, Charles; Engen, Eric; Hassett, Kevin A. and Hubbard, R. Glenn. "Do Budget Deficits Announcements Move Interest Rates?" Unpublished manuscript, December 22, 2003.

Efron, Bradley and Tibshirani, Robert J. Introduction to the Bootstrap. New York: Chapman and Hall, 1993.

Faust, Jon; Rogers, John H.; Wang, Shing-Yi B. and Wright, Jonathan H. "The High-Frequency Response of Exchange Rates and Interest Rates to Macro- 
economic Announcements." Journal of Monetary Economics (forthcoming, 2006).

Fleming, Michael J. and Remolona, Eli M. "What Moves the Bond Market?" Federal Reserve Bank of New York Economic Policy Review, December 1997, 3(4), pp. 31-50.

Fleming, Michael J. and Remolona, Eli M. "What Moves Bond Prices?" Journal of Portfolio

Management, Summer 1999, 25(4), pp. 28-38.

Greene, William H. Econometric Analysis. 5th ed. Upper Saddle River: Prentice Hall, 2003.

Gürkaynak, Refet S.; Sack, Brian P. and Swanson, Eric T. "Market-Based Measures of Monetary Policy Expectations." Working Paper, Division of Monetary Affairs, Board of Governors of the Federal Reserve System, August 1, 2002; www.federalreserve.gov/ pubs/feds/2002/200240/200240pap.pdf.

Gürkaynak, Refet S.; Sack, Brian P. and Swanson, Eric T. "The Excess Sensitivity of Long-Term Interest Rates: Evidence and Implications for Macroeconomic Models." Working paper, Division of Monetary Affairs, Board of Governors of the Federal Reserve System, April 4, 2003; www.clevelandfed.org/ CentralBankInstitute/conf2003/august/ sensitivity_apr4.pdf.

Gürkaynak, Refet S.; Sack, Brian P. and Swanson, Eric T. "The Sensitivity of Long-Term Interest Rates to Economic News: Evidence and Implications for Macroeconomic Models.” American Economic Review, March 2005, 95(1), pp. 425-36.

Kohn, Donald L. and Sack, Brian P. "Central Bank Talk: Does it Matter and Why?" Paper presented at the Macroeconomics, Monetary Policy, and Financial Stability Conference in Honor of Charles Freedman, Bank of Canada, Ottawa, Canada, June 20, 2003; www.federalreserve.gov/boarddocs/speeches/ 2003/20030620/paper.pdf.
Kuttner, Kenneth N. "Monetary Policy Surprises and Interest Rates: Evidence from the Fed Funds Futures Market." Journal of Monetary Economics, June 2001, 47(3), pp. 523-44.

Newey, Whitney K. and West, Kenneth D. "A Simple, Positive Semi-definite, Heteroskedasticity and Autocorrelation Consistent Covariance Matrix." Econometrica, May 1987, 55(3), pp. 703-808.

Poole, William and Rasche, Robert H. "Perfecting the Market's Knowledge of Monetary Policy.” Journal of Financial Services Research, December 2000, 18(2/3), pp. 255-98.

Poole, William; Rasche, Robert H. and Thornton, Daniel L. "Market Anticipations of Monetary Policy Actions." Federal Reserve Bank of St. Louis Review, July/August 2002, 84(4), pp. 65-93.

Silverman, Bernard W. Density Estimation for Statistics and Data Analysis. London: Chapman and Hall/CRC Press, 1986.

USA Today. "Poole Sees Stable Economy Ahead," Money Section, February 22, 2005.

Watson, Mark W. "Commentary." Federal Reserve Bank of St. Louis Review, July/August 2002, 84(4), pp. 95-97.

Weiss, Laurence. "Inflation Indexed Bonds and Monetary Theory.” Economic Theory, 2006, 27(1), pp. 271-75.

Yellen, Janet. "Views on the Economy and Implications for Monetary Policy." Remarks delivered at the San Diego Community Leaders Luncheon, September 8, 2005. 
